\title{
PENGARUH TINGKAT KESEHATAN BANK TERHADAP PERTUMBUHAN LABA
}

\author{
${ }^{1}$ Nurhidayah, ${ }^{2}$ Yeni Purwitosari \\ ${ }^{1}$ Fakultas Ekonomi \& Bisnis Universitas Islam Malang \\ Email : nurhidayati@unisma.ac.id \\ ${ }^{2}$ Pengamat ekonomi dan manajemen \\ Email : yenipurwitosar@gmail.com
}

\begin{abstract}
Abstrak
Pertumbuhan laba dapat digunakan sebagai ukuran pencapaian bank dalam penilaian kinerja bank. Hal ini dapat dicapai jika tingkat kesehatan bank terdiri dari Rasio Kecukupan Modal, Kualitas Aktiva, Margin Bunga Bersih, Pengembalian Aktiva, Rasio Pinjaman terhadap Deposito dan Rasio Risiko Bunga sesuai dengan standar yang ditetapkan oleh pemerintah. Untuk penelitian ini bertujuan untuk menilai bagaimana pengaruh bank terhadap pertumbuhan laba, khususnya bank swasta non-asing nasional periode 2013-2014 yang berjumlah 23 bank. Dengan menggunakan pengujian hipotesis ditemukan bahwa Return On Asset dan Loan to Deposit Ratio berpengaruh positif terhadap tingkat pertumbuhan laba bank, sedangkan Capital Adequacy Ratio, kualiatas Asset, Net Profit Margin dan Risk Ratio interst tidak mempengaruhi pertumbuhan laba bank.
\end{abstract}

Kata kunci: Kesehatan, Pertumbuhan Pendapatan, Bank

\section{Abstract}

The profit growth can be used as a measure of achievement of a bank in the assessment of bank performance. This can be achieved if the level of health of banks consisting Capital Adequacy Ratio, Assets Quality, Net Interest Margin, Return on Assets, Loan to Deposit Ratio and Interest Risk Ratio in accordance with the standards set by the government. For this study aims to assess how the influence of the bank to profit growth, particularly private banks non-foreign national 2013-2014 period amounting to 23 banks. By using hypothesis testing found that the Return On Asset and Loan to Deposit Ratio positive effect on the growth rate of bank profits, while the Capital Adequacy Ratio, kualiatas Assets, Net Profit Margin and Risk Ratio interst does not affect the bank's profit growth.

Keywords: Health, Income Growth, Bank

\section{PENDAHULUAN}

Bank merupakan lembaga yang berperan sebagai perantara keuangan (financial intermediary) antar pihak-pihak yang memiliki kelebihan dana (surplus unit) dengan pihak-pihak yang memerlukan dana (deficit unit) melalui kegiatan perkreditan dan berbagai jasa yang diberikan, bank melayani kebutuhan pembiayaan serta sebagai lembaga yang berfungsi memperlancar aliran lalu lintas pembayaran (Dendawijaya, 2009). Dengan demikian, bank menjadi penggerak dan pendorong perekonomian suatu negara, sehingga setiap bank perlu meningkatkan kinerja keuangan dan laba bank.

Salah satu tujuan utama perusahaan umumnya adalah memperoleh keuntungan/ laba dari kegiatan usahanya secara maksimal yang ditunjukkan dalam laporan keuangan perusahaan. Pertumbuhan laba 
dapat digunakan sebagai ukuran dari prestasi yang dicapai suatu bank dalam penilaian kinerja bank (Simorangkir, 2005).

Bank dengan laba yang bertumbuh menunjukkan bahwa bank tersebut memiliki keuangan yang fleksibel dan kemampuan operasional yang baik sehingga pertumbuhan labanya pun meningkat (Dewanti, 2009). Pertumbuhan laba selain digunakan untuk menilai kinerja bank, juga dilihat sebagai salah satu bentuk pertanggungjawaban kepada para stakeholder, pertanggungjawaban itu juga harus disertai dengan usaha untuk memperoleh kepercayaan masyarakat terhadap dana yang telah dipercayakan kepada bank tersebut.

Pentingnya menjaga kepercayaan masyarakat terhadap bank karena kegiatan utama bank adalah menghimpun dana dari masyarakat kemudian menyalurkannya dengan tujuan untuk memperoleh pendapatan. Oleh karenanya Bank Indonesia menerapkan aturan tentang kesehatan bank untuk menilai kinerja bank. Kesehatan bank dapat diartikan sebagai kemampuan suatu bank untuk melakukan kegiatan operasional perbankan secara normal dan mampu memenuhi semua kewajibannya dengan baik dengan cara-cara yang sesuai dengan peraturan perbankan yang berlaku (Budisantoso dan Triandaru, 2005). Dengan adanya aturan tentang kesehatan bank ini, perbankan diharapkan selalu dalam kondisi sehat sehingga tidak akan merugikan masyarakat yang berhubungan dengan perbankan.

Untuk menilai kinerja perusahaan perbankan umumnya menggunakan beberapa aspek penilaian dilihat dari sisi tingkat kesehatan bank yang dibuat oleh Bank Indonesia. Sesuai dengan Peraturan Bank Indonesia Nomor 6/10/PBI/2004 Penilaian Tingkat Kesehatan Bank dapat diukur berdasarkan faktor CAMELS yang merupakan penilaian kesehatan bank terhadap enam faktor yakni Capital, Assets, Management, Earnings, Liqudity dan Sensitivity to Market Risk yang berpengaruh terhadap kondisi dan pertumbuhan laba bank.

\section{KAJIAN TEORI \\ Pengertian Kesehatan Bank}

Menurut Santoso dan Triandaru (2005) Kesehatan Bank merupakan kemampuan suatu bank untuk melakukan kegiatan operasional perbankan secara normal dan mampu memenuhi semua kewajibannya dengan baik dengan cara-cara yang sesuai dengan peraturan yang berlaku.

Secara sederhana dapat dikatakan bahwa bank yang sehat adalah bank yang dapat menjalankan fungsi-fungsinya dengan baik. Dengan kata lain, bank yang sehat adalah bank yang dapat menjaga dan memelihara kepercayaan masyarakat, dapat menjalankan fungsi intermediasi, dapat membantu kelancaran lalu lintas pembayaran, serta dapat dipergunakan oleh pemerintah dalam melaksanakan berbagai kebijakannya, terutama kebijakan moneter..

Oleh karena itu, adanya ketentuan tingkat kesehatan bank dimaksudkan untuk dapat digunakan sebagai (1) Tolok ukur bagi manajemen bank untuk menilai apakah pengelolaan bank telah dilakukan sejalan dengan asas-asas perbankan yang sehat dan sesuai dengan 
ketentuan-ketentuan yang berlaku. (2) Tolok ukur untuk menetapkan arah pembinaan dan pengembangan bank-bank secara individu maupun perbankan secara keseluruhan.

Mengingat peranan industri perbankan yang sangat strategis dalam suatu perekonomian, maka tingkat kesehatan bank sangat perlu untuk diperhatikan untuk menjaga tingkat kepercayaan masyarakat terhadap bank. Tingkat kepercayaan masyarakat terhadap lembaga perbankan hanya dapat ditumbuhkan apabila lembaga perbankan dalam kegiatan usahanya selalu berada dalam kondisi sehat (Satria, 2009).

\section{Tata Cara Penilaian Tingkat Kesehatan Bank}

Menyadari arti penting kesehatan suatu bank bagi pembentukan kepercayaan dalam dunia perbankan serta untuk melaksanakan prinsip kehati-hatian atau prudential banking dalam dunia perbankan, maka Bank Indonesia merasa perlu untuk menetapkan aturan mengenai kesehatan bank. Aturan kesehatan bank ini tertuang dalam Surat Edaran Bank Indonesia No. 6/23/DPNP tanggal 31 Mei 2004 mengenai tata cara penilaian tingkat kesehatan bank, bahwa tingkat kesehatan bank dapat diukur berdasarkan faktor CAMELS (Capital, Asset, Management, Earning, Liqudity dan Sensitivity to Market Risk) yang berpengaruh terhadap kondisi dan perkembangan suatu bank.

Tingkat kesehatan bank pada dasarnya dinilai dengan pendekatan kuantitatif atas berbagai aspek yang berpengaruh terhadap kondisi dan perkembangan suatu bank.Pendekatan kuantitatif tersebut dilakukan dengan menilai faktor-faktor penilaian tingkat kesehatan bank berdasarkan analisis CAMELS. Unsur-unsur penilaian dalam analisis CAMELS adalah sebagai berikut: (1) Capital Adequancy Ratio (CAR) adalah rasio yang memperlihatkan seberapa besar jumlah seluruh aktiva bank yang mengandung unsur risiko (kredit, penyertaan, surat berharga, tagihanpada bank lain) yang ikut dibiayai dari modal sendiri disamping memperoleh dana-dana dari sumber-sumber diluar bank. (2) Assets Quality (Kualitas Aktiva PRODUKTIF/ KAP) merupakan kualitas aset sehubungan dengan risiko kredit yang dihadapi bank akibat pemberian kredit dan investasi dana bank pada portofolio yang berbeda. Penilaian pada kualitas aktiva produktif didasarkan pada prospek usaha, kondisi keuangan membayar. (3) Untuk menilai kesehatan bank dalam aspek manajemen, biasanya dilakukan melalui kuisioner yang ditujukan bagi pihak manajemen bank antara lain meliputi penilaian terhadap komponen-komponen manajemen umum, penerapan sistem manajemen risiko, kepatuhan bank terhadap ketentuan yang berlaku, serta komitmen kepada Bank Indonesia dan pihak lainnya. (4) Penilaian terhadap faktor earnings (rentabilitas) meliputi penilaian terhadap kinerja earnings, sumber-sumber earnings, dan sustainaility earnings Bank. Tindakan pengawasan yang dilakukan antara lain meminta bank agar meningkatkan kemampuan menghasilkan laba seperti melalui peningkatan efisiensi dan volume usaha dengan tetap memperhatikan prinsip kehati-hatian. Penilaian faktor rentabilitas bank dapat menggunakan parameter Return on Assets. (5) Liquidity risk menunjukkan risiko yang 
dihadapi oleh bank karena mengalami kegagalan untuk memenuhi kewajiban terhadap deposannya, dengan alat-alat likuid yang tersedia karena harus digunakan oleh bank yang bersangkutan untuk membayar kewajiban yang harus segera dilunasi (callable liabilities). Penilaian faktor Liquidity bank dapat menggunakan parameter Loan to Deposit Ratio (LDR). (6) Menurut Sawir (2005) faktor sensitivitas terhadap resiko pasar dapat diproksikan dengan resiko suku bunga yang merupakan variabel paling dominan dalam menilai resiko pasar. Resiko suku bunga dalam penelitian ini bisa dilihat melalui rasio Interest Risk Ratio (IRR), dimana Interest Risk Ratio (IRR) itu sendiri merupakan rasio yang digunakan untuk mengukur kemungkinan bunga yang diterima oleh bank dibandingkan dengan bunga yang dibayarkan oleh bank.

\section{Pertumbuhan Laba}

Tujuan utama perusahaan umumnya adalah memperoleh keuntungan/ laba dari kegiatan usahanya secara maksimal. Perbankan adalah salah satu perusahaan yang bergerak di bisnis keuangan, juga memiliki tujuan yang sama dengan perusahaan pada umumnya yaitu memperoleh laba. Laba merupakan suatu peningkatana dalam ekuitas pemilik yang dihasilkan dari operasi perusahaan perbankan yang menguntungkan. Suwardjono (2005) mendefinisikan laba sebagai pendapatan dikurangi biaya merupakan pendefinisian secara struktural atau sintatik karena laba tak didefinisi secara terpisah dari pengertian pendapatan dan biaya.

Menurut Hanafi (2010) laba merupakan ukuran keseluruhan prestasi perusahaan, yang didefinisikan sebagai hasil pengurangan antara pendapatan dan biaya. Sementara pengertian laba yang dianut oleh struktur akuntansi sekarang ini adalah selisih pengukuran pendapatan dan biaya. Besar kecilnya laba sebagai pengukur kenaikan sangat bergantung pada ketepatan pengukuran pendapatan dan biaya.

\section{Gambar 1 \\ Kerangka Konseptual Penelitian}

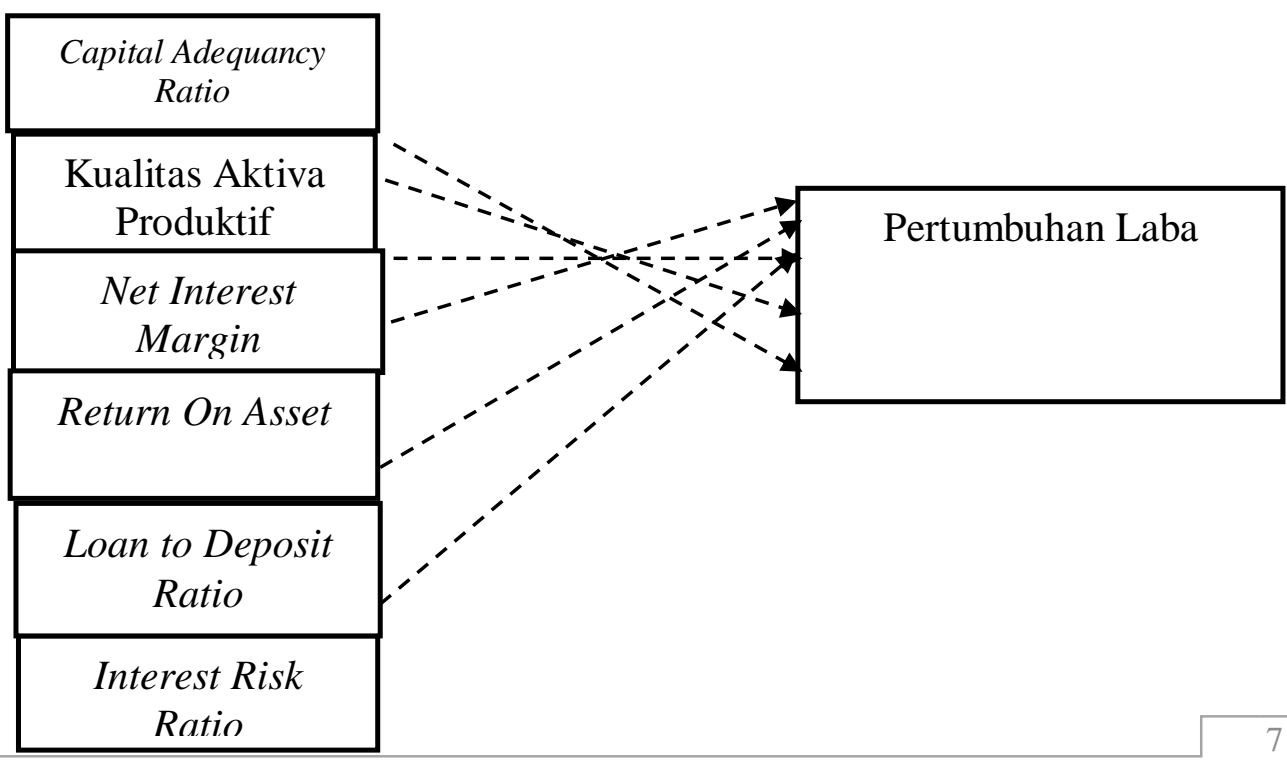




\section{Hipotesis}

Berdasarkan penelitian terdahulu dan kerangka konsep maka diuraikan hipotesis sebagai berikut:

H1 :Capital adequacy ratio berpengaruh terhadap pertumbuhan laba

$\mathrm{H} 2$ :Kualitas aktiva produktif berpengaruh terhadap pertumbuhan laba

H3 :Net interest margin berpengaruh terhadap pertumbuhan laba

H4 :Return on asset berpengaruh terhadap pertumbuhan laba

H5 :Loan to deposit ratio berpengaruh terhadap pertumbuhan laba

H6 :Interest risk ratio berpengaruh terhadap pertumbuhan laba

\section{METODE PENELITIAN \\ Populasi dan Sampel}

Menurut Sugiyono (2011) populasi adalah wilayah generalisasi yang terdiri atas obyek atau subyek yang mempunyai kuantitas dan karakteristik tertentu yang ditetapkan oleh peneliti untuk dipelajari dan kemudian ditarik kesimpulan. Populasi dalam penelitian ini adalah Bank Umum Swasta Nasional Non Devisa yang ada di Indonesia yang terdaftar dalam direktori Bank Indonesia yaitu 30 Bank.

Sampel menurut Sugiyono (2011) adalah bagian atau wakil populasi yang diteliti. Sampel merupakan sebagian dari populasi yang memiliki karakteristik yang relatif sama dan dianggap bisa mewakili populasi.Teknik sampling yang digunakan purposive sampling. Menurut Sugiyono (2011) teknik "purposive sampling" merupakan teknik penentuan sampel dengan pertimbangan tertentu. Adapun Kriteria yang digunakan dalam penelitian ini adalah bank umum swasta nasional non devisa yang merupakan bank konvensional bukan bank syari'ah yang terdiri 23 bank.

\section{Metode Analisis \\ Uji Asumsi Klasik}

Uji asumsi klasik dilakukan agar memperoleh nilai perkiraan yang tidak bias.

Uji asumsi klasik tersebut terdiri:

\section{Uji Autokorelasi}

Tujuan uji ini adalah untuk mengetahui apakah dalam sebuah model regresi linier ada korelasi antara kesalahan pengganggu pada periode $t$ dengan kesalahan pada periode t-1 (sebelumnya). Menurut Santoso (2011) untuk mendeteksi autokorelasi, dapat dilihat pada nilai D-W yaitu (a) Angka D-W di bawah -2, berarti ada autokorelasi positif. (b) Angka D-W di antara -2 sampai +2 , berarti tidak ada autokorelasi. (c) Angka D-W di atas +2 , berarti ada autokorelasi negatif.

\section{Uji Multikolonieritas}

Uji multikolonieritas bertujuan menguji apakah pada model regresi ditemukan adanya korelasi antar peubah independen. Jika terjadi korelasi, maka terdapat problem multiolonieritas. Untuk mendeteksi terdapat 
tidaknya multikolonieritas dapat menggunakan besaran Variance Inflation Factor and Tolerance (VIF). Pada umumnya, jika nilai VIF > 10, maka terdapat gejala multikolonieritas yang tinggi (Santoso, 2013)

\section{Uji Heterokesdastisitas}

Uji Heteroskedastisitas bertujuan untuk menguji apakah dalam model regresi terjadi ketidaksamaan varian dari residual satu pengamatan kepengamatan lainnya. Jika varian dari residual satu ke pengamatan yang lain tetap, maka disebut Homokedastisitas dan jika berbeda disebut Heterokedastisitas. Menurut Gujarati (2005) dasar untuk mendeteksi ada

atau tidaknya heteroskedastisitas adalah (a) Jika ada pola tertentu (bergelombang, melebar kemudian menyempit) maka mengindikasikan telah terjadi heteroskedastisitas. (b) Jika tidak ada pola yang jelas, serta titik-titik menyebar diatas dan dibawah angka 0 pada sumbu $\mathrm{Y}$, maka tidak terjadi heteroskedastisitas.

\section{Uji Normalitas}

Uji normalitas bertujuan untuk menguji apakah dalam model regresi,variabel pengganggu atau residual memiliki distribusi normal atau tidak. Model regresi yang baik adalah memiliki distribusi normal atau mendekati normal. Menurut Ghozali (2006) cara mendeteksi dilakukan dengan dua cara yaitu (a) Jika data menyebar disekitar garis diagonal dan mengikuti arah garis diagonal, maka model regresi memenuhi asusmi normalitas. (b) Jika data menyebar jauh dari garis diagonal dan /tidak mengikuti arah garis diagonal, maka model regresi tidak memenuhi asumsi normalitas.

\section{Pengujian Hipotesis}

Untuk menguji hipotesis digunakan alat regresi sederhana yang diformulasikan sebagai berikut :

\section{Keterangan:}

$$
Y=b_{0}+b_{n} X_{n}+e i
$$

Y :Pertumbuhan laba

$\mathrm{X}_{\mathrm{n}} \quad: \mathrm{CAR} / \mathrm{KAP} / \mathrm{NIM} / \mathrm{ROA} / \mathrm{LDR} / \mathrm{RR}$

$\mathrm{B}_{0} \quad$ : Bilangan konstanta

$\mathrm{B}_{1} \quad$ : Pengaruh peubah $\mathrm{X}_{1}$

Ei : Error

Uji signifikansi secara parsial menggunakan uji t dengan pengujian sebagai berikut:

Jika thitung $>\mathrm{t}$ tabel maka Ho ditolak

Jika t hitung $<\mathrm{t}$ tabel maka $\mathrm{HO}$ diterima

\section{HASIL ANALISIS DATA}




\section{Uji Asumsi Klasik}

\section{Uji Multikolonieritas}

Dari hasil pengujian multikolonieritas menunjukkan bahwa semua peubah memiliki nilai VIF $<10$ sehingga dapat disimpulkan bahwa asumsi multikolonieritas terpenuhi. Adapun hasil uji multikolonieritas sebagai berikut:

Tabel 1

Hasil Uji Multikolinieritas

\begin{tabular}{|c|c|c|c|}
\hline \multirow[b]{2}{*}{ Model } & & \multicolumn{2}{|c|}{ Collinearity Statistics } \\
\hline & & Tolerance & VIF \\
\hline & CAR & .473 & 2.114 \\
\hline & KAP & .647 & 1.546 \\
\hline & NIM & .546 & 1.830 \\
\hline & ROA & .687 & 1.455 \\
\hline & LDR & .669 & 1.495 \\
\hline & IRR & .378 & 2.646 \\
\hline
\end{tabular}

\section{Uji Autokorelasi}

Tabel 2

Hasil Uji Autokorelasi

\begin{tabular}{|l|r|r|r|r|r|}
\hline Model & $\mathrm{R}$ & R Square & $\begin{array}{c}\text { Adjusted R } \\
\text { Square }\end{array}$ & $\begin{array}{c}\text { Std. Error of } \\
\text { the Estimate }\end{array}$ & Durbin-Watson \\
\hline 1 & $.527^{\mathrm{a}}$ & .277 & .166 & .62475 & 1.876 \\
\hline
\end{tabular}

a. Predictors: (

b. Constant), IRR, KAP, ROA, LDR, NIM, CAR

b. Dependent Variable: PERTLABA 
Uji autokorelasi penelitian ini dapat dilihat pada nilai Durbin-Watson dan memiliki distribusi diantara -2 sampai +2. Nilai Durbin-Watson penelitian ini memiliki nilai sebesar 1.876 yang artinya bahwa model regresi di atas tidak terdapat masalah autokorelasi karena angka 1.876 berada di poin b nilai patokan Durbin-Watson di atas yaitu berada pada angka D-W di antara -2 sampai +2 atau dapat disimpulkan tidak terjadi autokorelasi.

\section{Pengujian Hipotesis}

Tabel 3

Hasil Uji t

\section{Coefficients $^{\mathrm{a}}$}

\begin{tabular}{|l|r|r|r|r|r|}
\hline \multirow{2}{*}{ Model } & \multicolumn{2}{|c|}{$\begin{array}{c}\text { Unstandardized } \\
\text { Coefficients }\end{array}$} & \multicolumn{2}{c|}{$\begin{array}{c}\text { Standardized } \\
\text { Coefficients }\end{array}$} & \multicolumn{1}{c|}{} \\
\cline { 2 - 5 } & \multicolumn{1}{|c|}{$\mathrm{B}$} & Std. Error & \multicolumn{1}{c|}{ Beta } & \multicolumn{1}{c|}{$\mathrm{t}$} & \multicolumn{1}{c|}{ Sig. } \\
\hline (Constant) & -1.461 & 1.534 & & -.953 & .347 \\
CAR & .712 & .505 & .279 & 1.410 & .166 \\
KAP & .012 & .053 & .038 & .223 & .825 \\
NIM & .035 & .043 & .148 & .804 & .426 \\
ROA & .385 & .130 & .487 & 2.965 & .005 \\
LDR & 1.796 & .693 & .432 & 2.594 & .013 \\
IRR & -1.614 & 1.054 & -.339 & -1.532 & .134 \\
\hline
\end{tabular}

a. Dependent Variable: PERTLABA

Dalam penelitian ini analisis regresi berganda dilakukan untuk mengetahui pengaruh yang diakibatkan oleh variabel bebas (independent variable) terhadap variabel terikat (dependent variable). Dari tabel 3 dapat didapatkan sebuah persamaan regresi berganda sebagai berikut:

$$
\begin{aligned}
\mathrm{Y}= & -1.461+0.721 \mathrm{X} 1+0.012 \mathrm{X} 2+0.035 \mathrm{X} 3+0.385 \mathrm{X} 4+1.796 \mathrm{X} 5- \\
& 1.614 \mathrm{X} 6+0.62475
\end{aligned}
$$

Hasil uji t menunjukkan nilai $t_{\text {hitung }}>t_{\text {tabel }}$ maka Ho ditolak dan $\mathrm{H}_{1}$ diterima. Berdasarkan tabel diatas untuk variable return on asset (ROA) dan loan to deposit ratio (LDR) berpengaruh positif terhadap pertumbuhan laba bank karena nilai sig $<0.05$ dan nilai $t_{\text {hitung }}>t_{\text {tabel }}$, sementara capital adequacy 
ratio (CAR), kualitas aktiva produktif (KAP), net interest margin (NIM) dan interest rate (IRR) tidak berpengaruh terhadap pertumbuhan laba.

\section{PEMBAHASAN \\ Pengaruh Capital Adequacy Ratio Terhadap Pertumnuhan Laba}

Capital Adequancy Ratio tidak berpengaruh signifikan terhadap pertumbuhan laba, Capital Adequancy Ratio merupakan permodalan bagi semua bank yang digunakan sebagai penyangga kegiatan operasional sebuah bank maupun penyangga terhadap kemungkinan terjadinya kerugian. Semakin tinggi Capital Adequancy Ratio maka semakin baik kondisi bank yang akan meningkatkan kinerja bank terutama dalam perolehan laba, tetapi pada penelitian ini Capital Adequancy Ratio) tidak berpengaruh terhadap pertumbuhan laba, hal ini dapat dilihat pada data dimana sebagian besar data ketika nilai Capital Adequancy Ratio (CAR) mengalami kenaikan, tetapi pada nilai pertumbuhan labanya mengalami penurunan. Hal ini dikarenakan modal yang dimiliki oleh bank hanya digunakan untuk memenuhi ketentuan penyediaan modal minimum dari Bank Indonesia sebesar 8\%, selain itu Capital Adequancy Ratio yang tidak berpengaruh mengindikasikan adanya indikasi potensi yang belum teroptimalkan dalam perbankan yaitu modal yang berlebihan, hal tersebut memberikan gambaran bahwa bank belum melakukan pengelolaan modal bank dalam kegiatan operasionalnya secara optimal yaitu kurangnya intermediasi yang dilakukan oleh bank yang bersangkutan, terutama dalam meningkatkan pertumbuhan penyaluran kredit secara optimal, sehingga menyebabkan kurangnya pendapaan dari bunga kredit yang diberikan. Hasil penelitian ini sejalan dengan penelitian yang dilakukan Daniariga (2011) dan Wirawan (2013)

\section{Pengaruh Kualitas Aktiva Produktif Terhadap Pertumbuhan Laba}

Variabel Kualitas Aktiva Produktif berpengaruh negatif terhadap pertumbuhan laba. Hal ini disebabkan ini disebabkan karena perbankan walaupun telah membentuk Kualitas Aktif Produktif yang sesuai dengan ketentuan dari Bank Indonesia tetapi didalam kegiatan operasionalnya masih memiliki kredit bermasalah maka akan berdampak pada kesehatan bank tersebut karena laba yang dimiliki oleh perbankan akan relative tidak stabil sehingga asset tidak berpengaruh didalam kinerja keuangan terutama dalam perolehan laba bank. Hal ini sejalan dengan penelitian Anggraeni (2014)

\section{Pengaruh Net Interest Margin Terhadap Pertumbuhan Laba}

Variabel Net Interest Margin tidak berpengaruh terhadap variabel pertumbuhan laba, hal ini menunjukkan bahwa manajemen bank belum mampu mengelola aktiva produktifnya untuk menghasilkan pendapatan terutama dari Spread bunga tabungan, dan kredit, mengingat pendapatan operasional bank sangat tergantung dari selisih bunga dari kredit yang disalurkan. Selain itu, peningkatan aktiva produktif berupa peningkatan atas kredit yang diberikan akan menghasilkan pendapatan bunga yang juga cenderung meningkat. Akan tetapi terdapat kredit macet yang juga 
meningkat hampir setiap tahunnya. Kredit bermasalah yang meningkat akan menurunkan nilai pendapatan bunga. Untuk itu pihak bank tidak langsung menaikkan bunga kredit karena akan memengaruhi angsuran dan menyebabkan rasio kredit bermasalah meningkat, tetapi dengan meningkatkan volume kredit. Hasil penelitian ini sesuai dengan hasil penelitian terdahulu yang dilakukan oleh Anggraeni (2014) dan tidak sesuai dengan penelitian terdahulu yang dilakukan Wirawan (2014) dan penelitian Paulak (2014), dimana hasil penelitiannya menunjukkan bahwa Net Interest Margin berpengaruh positif terhadap pertumbuhan laba.

\section{Pengaruh Return On Asset Terhadap Pertumbuhan Laba}

Variabel Return On Assets berpengaruh positif dan signifikan terhadap pertumbuhan laba. Hal ini menunjukkan bahwa bank sudah mampu mengelola asset yang dimiliki untuk digunakan dalam kegiatan operasional bank untuk memperoleh laba. Semakin besar Return On Assets semakin besar pula tingkat keuntungan yang dicapai bank tersebut. Sehingga kemungkinan suatu bank dalam kondisi bermasalah semakin kecil. Hasil penelitian ini sesuai dengan penelitian yang dilakukan Wirawan (2013) yang menunjukkan bahwa Return On Assets berpengaruh terhadap pertumbuhan laba.

\section{Pengaruh Loan To Deposit Ratio Terhadap Pertumbuhan Laba}

Variabel Loan to Deposit Ratio berpengaruh positif terhadap pertumbuhan laba. Dengan kata lain, seberapa jauh pemberian kredit kepada nasabah, dapat mengimbangi kewajiban bank untuk segera memenuhi permintaan deposan yang ingin menarik kembali uangnya yang telah digunakan oleh bank untuk memberikan kredit. Semakin tinggi rasio ini, mengindikasikan semakin rendahnya kemampuan likuiditas bank yang bersangkutan. Di lain pihak, kondisi Loan to Deposit Ratio yang semakin tinggi dapat diartikan bahwa semakin besar kredit yang disalurkan kepada masyarakat, yang akan meningkatkan pendapatan bunga bank dan akan mengakibatkan kenaikan laba. Karena salah satu sumber keuntungan (laba) bank adalah berasal dari pinjaman kredit. Dengan demikian tinggi rendahnya Loan to Deposit Ratio juga dapat mempengaruhi perolehan laba, Loan to Deposit Ratio yang tinggi berarti jumlah kredit yang disalurkan semakin tinggi, sehingga akan menyebabkan laba meningkat. Tetapi jika sebaliknya, pinjaman kredit menurun diikuti rendahnya kemampuan untuk melunasi kewajibannya, maka pertumbuhan laba perusahaan pun akan turun. Nilai positif pada koefisien variabel Loan to Deposit Ratio menunjukkan sebagian besar data pada periode penelitian ketika nilai Loan to Deposit Ratio mengalami kenaikan, diikuti dengan kenaikan nilai pertumbuhan laba. Hal ini sesuai dengan penelitian Daniariga (2011) dan penelitian Patulak (2014).

\section{Pengaruh Interest Risk Ratio Terhadap Pertumbuhan Laba}


Variabel Interest Risk Ratio ( menunjukkan hasil tidak berpengaruh terhadap pertumbuhan laba. Hal ini disebabkan karena dalam dunia perbankan di Indonesia, dimana persaingan bisnis yang semakin ketat, maka dalam penawaran kredit kepada masyarakat antara bank satu dengan bank lainnya memiliki kecenderungan dengan beban bunga yang hampir sama, yang disesuaikan dengan suku bunga bank yang dikeluarkan oleh Bank Indonesia, sehingga pihak bank tidak dapat mengambil kebijakan untuk meningkatkan suku bunga kredit diatas rata-rata, karena nasabah akan cenderung beralih pada bank yang menawarkan kredit dengan bunga yang lebih rendah. Dengan demikian pertumbuhan laba yang terjadi pada perusahaan perbankan, lebih disebabkan karena pertumbuhan bank itu sendiri dan faktor-faktor lainnya, bukan disebabkan karena besar kecilnya suku bunga kredit yang berpengaruh terhadap pendapatan kreditnya. Hasil penelitian ini sesuai dengan penelitian yang dilakukan Wirawan (2013).

\section{SIMPULAN DAN SARAN}

Dari analisis yang telah dilakukan pada penelitian ini menemukan bahwa variabel Capital Adequancy Ratio, Kualitas Aktiva Produktif, Net Interest Margin, dan Interest Risk Ratio tidak berpengaruh signifikan terhadap Pertumbuhan Laba. Sementara variabel Return On Assets dan Loan to Deposit Ratio berpengaruh positif dan signifikan terhadap Pertumbuhan Laba .

Penelitian selanjutnya perlu mempertimbangkan variabel ekonomi makro Diharapkan yang dapat mempengaruhi pertumbuhan laba seperti pendapatan perkapita dan inflasi untuk lebih menjamin keakuratan hasil penelitian.

\section{DAFTAR PUSTAKA}

Anggraeni, Fitria, 2014, "Pengaruh CAR, NIM, KAP, LDR, dan Inflasi Terhadap Pertumbuhan Laba Pada Bank Umum Swasta Nasional Devisa Yang Terdaftar Di Bursa Efek Indonesia Periode 2008 2013". Jurusan Akuntansi Fakultas Universitas Pandanaran, Semarang.

Bank Indonesia, Laporan Keuangan Publikasi Bank, (www.bi.go.id)

Daniariga, Erros 2011, "Pengaruh Rasio Camel (CAR, RORA, NPM, BOPO, dan LDR Terhadap Pertumbuhan Laba (Pada Perusahaan Perbankan Yang Terdaftar Di Bursa Efek Indonesia) Periode 20082010”. Universitas Pembangunan Nasional Veteran, Yogyakarta

Darsono, Suwardjono dan Ashari, 2005, Pedoman Praktis Memahami Laporan Keuangan, Yogyakarta.

Dendawijaya, Lukman, 2009, Manajemen Perbankan, Ghalia Indonesia, Jakarta Selatan

Desmalini, 2014, "Pengaruh IRR, CAR, NPM, BOPO, dan LDR Terhadap Pertumbuhan Laba Pada Perusahaan Perbankan yanga Terdaftar di Bursa Efek Indonesia Periode 2009-2012". Jurusan Akuntansi Fakultas Ekonomi Universitas Maritim Raja Ali Haji Tanjungpinang Ghozali, Imam, 2006 , Aplikasi Analisis Multivariate dengan Program SPSS, Semarang: Badan Penerbit Universitas Diponegoro. 
Harahap, Zainuddin dan Hartono. 2008. "Manfaat Rasio Keuangan Dalam Memprediksi Pertumbuhan Laba", Dalam Jurnal Riset Akuntansi Indonesia, Vol 2. No. 1 Januari 2008, hal. 66-90.

Hasibuan, SP, 2008, Dasar-Dasar Perbankan, cetakan ketiga, Penerbit : Bumi

Aksara, Jakarta

Horman, Christi, 2012,"Analisis Faktor-Faktor Yang Berpengaruh Terhadap Profitabilitas Bank Yang Terdaftar Pada BEI Selama Tahun 20082010". Fakultas Ekonomi Akuntansi Universitas Negeri Surakarta

Kasmir, 2004, Manajemen Perbankan, Edisi Pertama, Cetakan Ketiga, Grafindo Persada, Jakarta.

Kuncoro, 2010, Metode Penelitian, Salemba Empat, Jakarta.

Mamduh M. Hanafi dan Abdul Halim, 2009, Analisis Laporan Keuangan, UPP Yogyakarta, Yogyakarta.

Merkusiwati, Setyani, 2007, "Analisis Rasio Keuangan terhadap Perubahan Kinerja pada Perusahaan di Industri Food and Baverage yang Terdaftar di BEJ", Makalah yang disampaikan pada Simposium NasionalAkuntansi VIII, Solo, 15-16 September

Nugraheni, Artwienda, 2010, "Analisis Pengaruh Rasio Camels Terhadap Pertumbuhan Laba (Studi pada Perusahaan Perbankan Yang Terdaftar Di BEI Periode 2005-2008)". Jurusan Pendidikan EkonomiFakultas Ekonomi Universitas Negeri Yogyakarta

Nurhafita dan Dharma Tintri, 2010, "Rasio Keuangan yang Paling Baik untuk Memprediksi Pertumbuhan Laba, Jurnal Ekonomi dan Bisnis", Vol XI, No 2,September

OP Simorangkir., Drs., Ek., 2005. Seluk Beluk Bank Komersial, Edisi Revisi. Jakarta : Aksara Persada Indonesia.

Patulak, Natalia, 2014, "Analisis Pengaruh LDR, NPL, NIM, Dan BOPO Terhadap Pertumbuhan Laba Pada Bank BUMN Di Indonesia Yang Terdaftar Di Bei Tahun 2005 - 2012”, Jurusan Manajemen, Fakultas Ekonomi Dan Bisnis, Universitas Hasanuddin, Makassar.

PBI No.7/2/PBI/ 2005 tanggal 20 januari 2005 tentang penilaian Kualitas Aktiva Bank Umum

Peraturan Bank Indonesia No.6/10/PBI/2004 tentang Sistem Penilaian Tingkat Kesehatan Bank Umum.

Prayogi, A, 2012, "Analisis Pengaruh Rasio Keuangan Terhadap Tingkat Pertumbuhan (Studi Kasus pada Bank Pemerintah", Jurnal Fakultas Ekonomi Universitas Gunadarma.

Riyadi, 2006“Analisis Pengaruh Fakor-faktor Fundamental Perusahaan". DIPONEGORO, JOURNAL OF ACCOUNTING Vol.2 No.2

Satria, Dias, 2009, EKONOMI, UANG DAN BANK Catatan Teoritis dan Praktis, Cetakan Pertama, Universitas Brawijaya Press (UB Press) Malang

Sawir, A, 2005, Analisis Kinerja Keuangan dan Perencanaan Keuangan Perusahaan, Jakarta : PT. Gramedia Pustaka Utama.

Setyorini, 2012, "Analisis Pengaruh Rasio Camel Terhadap Tingkat Kesehatan Bank Pada Bank Umum Swasta Nasional Di Indonesia 
Periode 2007-2011”, Skripsi. Jurusan Manajemen Fakultas Ekonomi Universitas Sebelas Maret, Surakarta

Sugiyono, 2011, Statistika Untuk Penelitian, Alfabeta, Bandung.

-------, 2011, Metode Peneilitian Kuantitatif, Kuaitatif, dan R\&D, Alfabeta, Bandung

Surat Edaran Bank Indonesia No.6/23/DPNP tanggal 31 Mei 2004

Suwardjono, 2005, Teori Akuntansi : Perekayasaan Pelaporan Keuangan, Edisi Ketiga, BPFE Yogyakarta

Takarini, Nurjanti dan Erni Ekawati, 2009, “Analisis Rasio Keuangan dalam Memprediksi Perubahan Laba pada Perusahaan Manufaktur di Pasar Modal Indonesia", Ventura, Vol. 6, No. 3.

Triandaru, Sigit dan Totok Budisantoso, 2008, Bank Dan Lembaga Keuangan Lain, Salemba Empat, Jakarta.

Triono, 2009, "Analisis Faktor-Faktor yang Mempengaruhi Perubahan Laba Satu Tahun Mendatang dan Dua Tahun Mendatang (Studi pada Bank Umum di Indonesia Periode Tahun 2001-2005)", Tesis Program Pasca Sarjana Magister Manajemen Universitas Diponegoro

Yudha Wirawan, Rizki, 2013, Analisis Tingkat Kesehatan Keuangan Terhadap Pertumbuhan Laba Pada Perusahaan Bumn Sektor Perbankan Di Indonesia. Jurusan Manajemen, Fakultas Ekonomi Dan Bisnis, Universitas Hasanuddin, Makassar. 